\title{
PENERAPAN TEKNOLOGI PAKAN DAN LIMBAH TERNAK DALAM MENINGKATKAN PRODUKTIVITAS SAPI PEDAGING DI DESA BALANGTANAYA KEC. POLOMBANGKENG UTARA KAB. TAKALAR SULAWESI SELATAN
}

\author{
M.I. Said ${ }^{1}$, R.F. Utamy ${ }^{2}$ dan St. Rohani ${ }^{3}$
}

\begin{abstract}
ABSTRAK
Salah satu upaya yang dapat dilakukan untuk meningkatkan produktivitas ternak adalah dengan melakukan perbaikan nutrisi serta lingkungan ternak. Kondisi kekurangan pakan dan produksi limbah ternak yang besar merupakan salah satu permasalahan yang dihadapi oleh mitra. Perguruan tinggi sebagai salah wadah yang bertanggungjawab dalam memberikan solusi merasa perlu melakukan upaya sosialisasi dan transfer teknologi khususnya terkait dengan permasalahan pakan dan limbah ternak. Program pengabdian masyarakat ini bertujuan untuk memberikan pembelajaran bagi mitra kelompok tani-ternak terkait dengan terapan teknologi dalam memproduksi pakan fermentasi sebagai cadangan pakan pada musim paceklik serta pengolahan limbah ternak khususnya urin menjadi pupuk organik cair (POC). Kegiatan yang dilakukan merupakan wujud kepedulian perguruan tinggi terhadap kondisi dan produktivitas usaha peternakan rakyat yang semakin menurun. Kegiatan terapan teknologi telah dilaksanakan di Desa Balangtanaya, Kec. Polombangkeng Utara, Kab.Takalar. Kelompok mitra yang terlibat adalah kelompok tani-ternak "Sikatutui". Beberapa paket teknologi yang telah didiseminasikan antara lain paket : 1) teknologi amoniasi jerami, 2) teknologi pakan silase komplit fermentasi, 3) teknologi pembuatan mikroorganisme lokal (MOL) serta 4) teknologi pembuatan Urea Molasses Block (UMB). Metode terapan teknologi dilakukan melalui kegiatan pelatihan dalam bentuk tatap muka dan praktek. Selanjutnya dilakukan upaya pendampingan dan monitoring. Hasil pelaksanaan kegiatan menunjukkan bahwa kegiatan penerapan teknologi memberikan dampak yang sangat positif bagi mitra dalam meningkatkan kapasitas khususnya terkait dengan kemampuan dalam mengolah dan memproduksi pakan fermentasi serta mengolah limbah ternak menjadi produk komersial.
\end{abstract}

Kata Kunci: teknologi, kelompok, pakan, limbah ternak, sapi pedaging

\begin{abstract}
One of the efforts made to increase livestock productivity is to improve nutrition and livestock environment. The lack of feed supply and large waste production is one of the partners' problems. Higher education as an institution is fully responsible for providing solutions. Higher education institutions need to make efforts to disseminate and transfer technology specifically related to animal feed and waste problems. The community service program aims to increase the knowledge of partner farmer groups related to applied technology to produce fermented feed. This feed is a feed reserve in the dry season and processing of liquid waste in the form of urine into liquid organic fertilizer (LOF). The activities carried out are a manifestation of the university's concern for the condition and productivity of the people's livestock business which

\footnotetext{
${ }^{1}$ Dosen Departemen Produksi Ternak, Fakultas Peternakan Universitas Hasanuddin, irfanunhas@gmail.com

${ }^{2}$ Dosen Departemen Produksi Ternak, Fakultas Peternakan Universitas Hasanuddin, rennyfatmyahutamy198@gmail.com

${ }^{3}$ Dosen Departemen Sosial Ekonomi, Fakultas Peternakan Universitas Hasanuddin, nanirohani24@yahoo.co.id
} 
is declining. An applied technology activities have been carried out in Balangtanaya Village, North Polombangkeng Subdistrict, Takalar Regency. The partner groups involved are "Sikatutui" farmer groups. Technology packages that have been disseminated include: 1) straw ammonia technology, 2) fermented silage, 3) making local microorganisms (LM) and 4) making Urea Molasses Block (UMB). Applied technology methods are carried out through training activities in the form of face to face and practice. Next is the assistance and monitoring effort. The results of the implementation of the activities indicate that the application of technology has had a very positive impact on partners in increasing capacity specifically related to the ability to process and produce fermented feed and treat livestock waste into commercial products.

Keywords: technology, group, feed, animal waste, beef cattle

\section{PENDAHULUAN}

Salah satu permasalahan mendasar yang terjadi pada sektor peternakan akhir-akhir ini adalah adanya kecenderungan terjadinya penurunan produktivitas. Hal tersebut tercermin dari masih rendahnya pertambahan bobot harian rata-rata ternak khususnya ternak yang diperlihara secara tradisional. Sistem pemeliharaan ternak secara tradisional belum mampu memperbaiki produktivitas ternak yang berdampak langsung pada penghasilan para peternak. Rendahnya bobot harian dan angka kebuntingan maupun status kesehatan ternak yang dipelihara secara tradisional tidak terlepas dari tingkat pengetahuan para peternak terkait teknologi yang terbilang masih sangat rendah.

Introduksi teknologi maupun inovasi dalam bidang peternakan harus terus diupayakan untuk disosialisasikan kepada para petani dan peternak. Berbagai informasi teknologi dan inovasi terbaru yang telah dikembangkan di perguruan tinggi hendaknya dapat diterapkan pada mitra (petani dan peternak) secara penuh dan berkelanjutan. Sebagai respon terhadap hal tersebut, maka tim dosen dari Fakultas Peternakan Unhas yang bekerjasama dengan pihak Lembaga Penelitian dan Pengabdian kepada Masyarakat (LP2M) Unhas telah mengadakan kegiatan penerapan dan introduksi teknologi serta inovasi kepada para peternak sapi pedaging di Desa Balangtanaya, Kecamatan Polombangkeng Utara, Kabupaten Takalar.

Sejalan dengan Rencana Pembangunan Jangka Menengah Daerah (RPJMD) Kabupaten Takalar, maka sektor peternakan ditempatkan sebagai salah satu sektor andalan Kabupaten Takalar (Pemda Takalar, 2017). Hal inilah yang menyebabkan pihak pemeritah daerah memberikan perhatian sepenuhnya pada sektor peternakan. Hal tersebut tentunya sangat beralasan pula karena ditunjuknya Kabupaten Takalar sebagai daerah "penyangga" kebutuhan daging di Sulawesi Selatan maupun nasional dalam rangka menyukseskan program Pemerintah Daerah Sulawesi Selatan yakni 'gerakan peningkatan populasi sapi dua juta ekor'. Posisi Kabupaten Takalar secara geografis terbilang sangat strategis, karena berada pada jalur arteri menuju kota-kota lain pada bagian selatan di wilayah provinsi Sulawesi Selatan. Selain itu daerah ini juga tepat berada di kawasan pesisir yang memungkinkan proses transportasi ternak antar pulau lewat jalur laut dapat dilakukan dengan mudah dan lancar. Kawasan Timur Indonesia (KTI) yang sebagian besar terdiri atas pulau-pulau sangat menguntungkan kabupaten Takalar dari sisi pengembangan perdagangan ternak khususnya ternak sapi pedaging yang kebanyakan diperdagangkan lewat jalur laut.

Kecamatan Polombangkeng Utara, Kabupaten Takalar dikenal sebagai kawasan sentra pengembangan ternak sapi pedaging dari jenis Sapi Bali di Sulawesi Selatan yang merupakan salah satu daerah pemasok daging di Sulawesi Selatan bahkan bisa dikatakan di Kawasan Timur Indonesia (KTI). Hal ini dibuktikan dengan populasi sapi pedaging yang saat ini mencapai 16.889 ekor atau sebesar 46,43\% dari total populasi sapi pedaging di Kabupaten Takalar (36.374 ekor) (Pemda Takalar, 2017). Berdasarkan data tersebut menunjukkan bahwa hampir setengah 
populasi sapi pedaging yang ada di Kabupaten Takalar, itu berada di Kecamatan Polombangkeng Utara. Dengan potensi daerah yang dimiliki tersebut, kabupaten Takalar akhirnya memiliki brand tersendiri sebagai daerah "pabrik daging" di Kawasan Timur Indonesia.

Kelompok Tani Ternak (KTT) "Sikatutui" merupakan kelompok peternakan sapi pedaging binaan Sub-Dinas Peternakan Kabupaten Takalar. Kelompok ini berlokasi di Desa Balangtanaya, Kecamatan Polombangkeng Utara, Kabupaten Takalar. Aspek produksi dan manajemen merupakan dua aspek utama yang menjadi permasalahan dalam pengelolaan usaha peternakan khususnya sapi pedaging di daerah ini. Kualitas, kuantitas serta kontinuitas pakan ternak yang masih sangat rendah merupakan salah satu permasalahan dalam bidang produksi. Tingginya harga bahan baku pakan ternak merupakan salah satu aspek penting, sehingga dengan demikian tentunya membutuhkan strategi tertentu (Andang dan Indartono, 2014). Selain itu, aspek limbah peternakan yang selama ini banyak dihasilkan dari usaha pertanian juga belum dimanfaatkan secara maksimal. Dari jumlah yang ada, kurang lebih 70-80\% dari kebutuhan biaya produksi dari usaha peternakan bersumber dari pakan ternak (Pasaribu, 2007) sehingga hal tersebut sangat penting untuk diperhatikan. Permasalahan yang terkait dengan masih rendahnya tingkat pengetahuan peternak dan aplikasi teknologi serta manejemen usaha menyebabkan usaha budidaya yang mereka geluti juga belum mampu berkembang secara lebih baik. Berdasarkan hal tersebut dapat dikatakan bahwa apabila hal ini terjadi dan dibiarkan secara terus menerus maka dikhawatirkan keberlanjutan usaha budidaya ternak sapi pedaging akan terancam.

Kegiatan introduksi teknologi ini merupakan salah satu program tahunan dari LP2M Universitas Hasanuddin melalui skim Program Pengabdian kepada Masyarakat Unhas (PPMU) Program Kemitraan-Masyarakat (PK-M) melalui pendanaan Bantuan Operasional Perguruan Tinggi Negeri (BOPTN) Unhas. Tujuan pelaksanaan program adalah: 1) untuk meningkatkan kapasitas peternakan terkait dengan teknologi dalam mengolah limbah pertanian dan peternakan menjadi pakan ternak serta pupuk organik, 2) sebagai sebuah sarana dalam melaksanakan Tri Dharma di Perguruan Tinggi (PT) yakni kegiatan pengabdian masyarakat. 3) Selain itu juga, program ini tentunya merupakan sebuah wujud kepedulian dari para dosen yang ada di PT untuk mengaplikasikan dan mengembangkan hasil inovasi dan temuan di PT kepada masyarakat peternak.

\section{METODE PELAKSANAAN}

Untuk memperoleh hasil yang maksimal dalam penerapan teknologi, maka perbaikan metode pelaksanaan kegiatan mutlak harus diperhatikan. Sebagai upaya untuk memaksimalkan proses pemecahan masalah melalui transformasi paket/alih teknologi pada kegiatan "Program Kemitraan-Masyarakat (PK-M)" ini, tentunya dibutuhkan sejumlah strategi dalam mendukung realisasi metode yang ditawarkan. Dari metode ini diharapkan, invensi serta inovasi teknologi yang diterapkan dapat diadopsi dan dimanfaatkan semaksimal mungkin oleh mitra baik saat program kegiatan ini dijalankan maupun pada saat kegiatan berakhir (pasca kegiatan).

Secara keseluruhan, metode dilakukan dalam bentuk kegiatan bertahap. Beberapa tahapan kegiatan yang telah dilakukan diantaranya: 1) proses sosialisasi dan identifikasi lapangan. Tujuan kegiatan ini adalah untuk mensosialisasikan kegiatan kepada mitra. Kegiatan sosialisasi dan identifikasi permasalahan menggunakan sistem penjaringan masalah. 2) introduksi teknologi. Kegiatan ini bertujuan untuk meningkatkan pemahaman secara mendalam terkait invensi dan inovasi teknologi yang diterapkan. Kegiatan ini dilakukan dalam bentuk pelatihan secara terpadu dan terintegrasi. 3) pembuatan demplot teknologi. Tahap ini bertujuan untuk memberikan pemahaman secara nyata kepada mitra pengguna. Kegiatan ini dirancang dalam bentuk demonstrasi langsung dalam mengolah suatu produk yang selanjutnya diwujudkan dalam bentuk pembuatan demplot. 


\section{HASIL DAN PEMBAHASAN}

\section{Kegiatan Sosialisasi}

Langkah awal yang dilakukan dalam menerapkan kegiatan ini adalah sosialisasi. Tujuan utama dari kegiatan ini adalah memberikan penjelasan dan pemahaman kepada mitra terkait rencana dan prosedur kegiatan nantinya yang akan dilakukan. Proses sosialisasi dilakukan secara bersamaan dengan proses identifikasi masalah yang berkembang di lapangan. Kegiatan sosialisasi dan identifikasi masalah dilakukan melalui wawancara secara langsung dengan mitra. Gambaran pelaksanaan kegiatan sosialisasi dilokasi mitra disajikan pada Gambar 1.
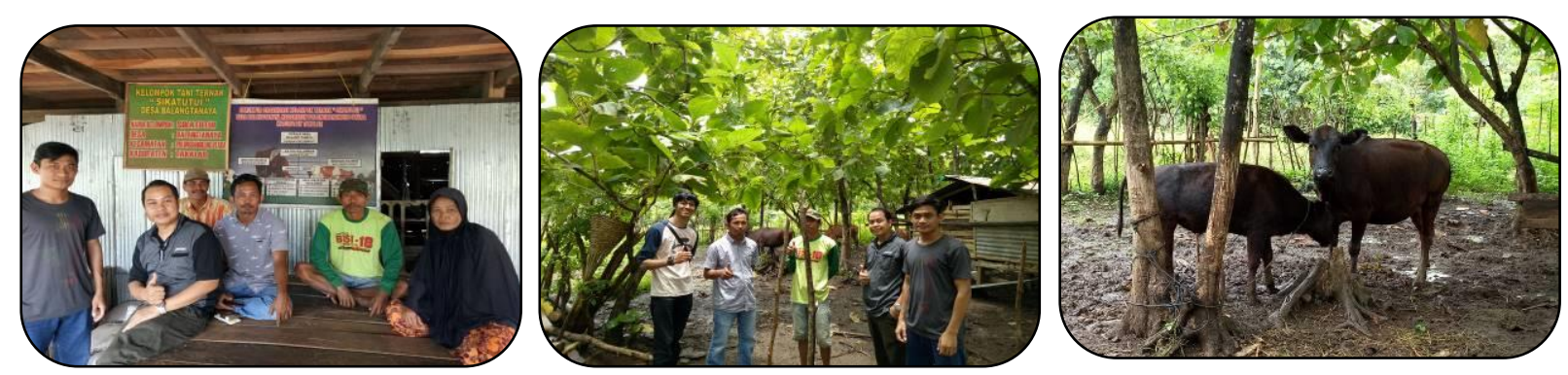

Gambar 1. Kegiatan sosialisasi kegiatan pada ketua kelompok tani ternak

"Sikatutui" di Desa Balangtanaya, Kec.Polombangeng Utara, Kab. Takalar

Berdasarkan hasil identifikasi lapangan selanjutnya diperoleh beberapa informasi dari para anggota kelompok tani/ternak terkait masalah-masalah yang dihadapi oleh peternak beserta dengan kendala-kendalanya. Permasalahan mendasar yang dihadapi oleh para mitra anggota kelompok adalah semakin berkurangnya ketersediaan pakan ternak. Bahan pakan ternak hanya mengandalkan pada pakan segar sehingga memungkinkan terjadinya kelangkaan pakan pada musim-musim tertentu. Selain itu limbah ternak belum termanfaatkan secara maksimal sedangkan jumlahnya sangat melimpah. Produksi limbah pertanian yang memadai merupakan potensi yang belum tergali secara konprehensif.

Pakan ternak yang sulit pada musim-musim tertentu merupakan pemasalahan yang membutuhkan solusi secara cepat. Dilain pihak bahwa potensi limbah pertanian yang dihasilkan masih cukup melimpah. Permasalahan kedua adalah masih minimnya upaya memanfaatkan limbah kotoran (feses) maupun urin sapi sebagai bahan baku pembuatan pupuk organik. Selanjutnya permasalahan ketiga adalah tingkat kualitas hijauan yang cenderung semakin rendah sehingga produktifitas ternak juga menjadi sangat rendah. Permasalahan-permasalahan inilah yang selanjutnya menjadi bahan masukan bagi pihak pelaksana untuk dicarikan solusinya.

\section{Kegiatan Pelatihan}

Peningkatan pemahaman mitra dalam suatu terapan teknologi akan semakin meningkat jika mitra dapat menyasikan langsung dan mencoba sendiri. Oleh karena itu dilakukan peningkatan kapasitas mitra melalui diskusi dan pemberian materi atau teori secara langsung.

Untuk meningkatkan pemahaman mitra kelompok tani maupun aparat pemerintah daerah tentang aplikasi teknologi, maka sebelumnya dilakukan peningkatan kapasitas yang diimplementasikan dalam bentuk pelatihan. Dalam pelatihan tersebut diikuti oleh sejumlah anggota mitra kelompok tani dan pemerintah daerah (dinas peternakan). Dokumentasi kegiatan pelatihan secara lengkap disajikan pada Gambar 2. 

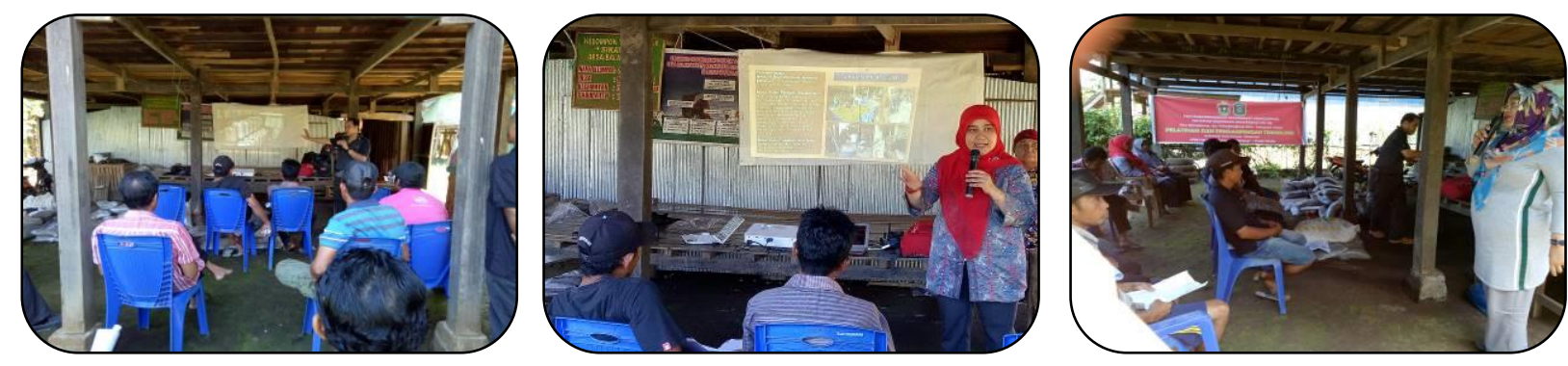

Gambar 2. Kegiatan peningkatan kapasitas dalam bentuk pelatihan dalam kegiatan PKM pada anggota kelompok tani ternak "Kurusumange" dan "Masempo Dalle" di Desa Mattirowalie, Kec.Libureng, Kab. Bone

Pada sesi pelatihan, kegiatan dibagi menjadi 2 tahapan, yakni pemaparan materi dan praktek langsung membuat produk. Beberapa inovasi teknologi yang diterapkan dalam kegiatan tersebut diantaranya teknik dan proses pengolahan pakan fermentasi dan pakan penguat, pengolahan limbah ternak, kesehatan ternak serta teknologi pembuatan Mikroorganisme lokal (MOL) sebagai dekomposer fermentasi alami. Aplikasi MOL sebagai dekomposer akhir-akhir ini banyak dipertimbangkan oleh para peneliti. Hal ini disebabkan karena MOL merupakan salah satu sumber mikroorganisme yang murah, relatif mudah diperoleh dan dikembangkan serta bersifat ramah lingkungan. MOL dapat diperoleh dari bahan hewani maupun dari nabati (Said, 2014).

Kegiatan ini dihadiri oleh sekitar 25 orang petani/peternak yang tergabung dalam kelompok tani/ternak "Sikatutui" dengan ketua kelompok Bangun Dg.Roa. Materi dalam transfer teknologi dibawakan oleh 3 orang pemateri yakni: adalah Dr. Muhammad Irfan Said, S.Pt, MP (Ketua Pelaksana Kegiatan) dengan judul materi "Pembuatan Pupuk Organik Cair Dari Urin Sapi dan Pembuatan Mikroorganisme Lokal (MOL) sebagai Dekomposer Pakan Dan Pupuk Organik". Pemateri 2 adalah Dr. Agr.Renny F. Utamy, S.Pt, M.Agr dengan judul materi "Pembuatan Urea Molases Block (UMB)". Pemateri 3 adalah Dr.Ir.Hj.St.Rohani, M.Si dengan materi "Prospek Pengembangan Sapi Potong".

Salah satu permasalahan mendasar dalam pengembangan usaha peternakan rakyat adalah tingkat produktivitas ternak yang belum optimal. Terdapat 3 konsep dan komponen penting yang harus diperbaiki dalam meningkatkan produktivitas ternak. Konsep tersebut diantaranya adalah pakan (feeding), perbibitan (breeding) serta aspek tatakelola (management). Konsep ini harus didukung oleh komponen lainnya. Beberapa komponen-komponen pendukung yang sangat penting diantaranya : pengolahan, pengemasan dan pemasaran hasil ternak, kesehatan serta pengolahan dan pemanfaatan limbah ternak. Inovasi teknologi dan temuan-temuan yang telah dikembangkan oleh perguruan tinggi perlu secara komprehensif disosialisasikan dan diintroduksikan khususnya bagi usaha peternakan rakyat.

Nilai nutrisi dalam limbah pertanian pada daerah tropis sangat rendah, sehingga dibutuhkan adanya suplai pakan tambahan untuk mencukupi kebutuhan ternak. Jumlah pakan yang diberikan pada ternak harus memenuhi kebutuhan ternak tersebut untuk hidup pokok maupun untuk berproduksi (Soeradji, 1978). Jenis pakan hijauan maupun konsentrat merupakan komponen ransum pada sapi yang merupakan sumber zat-zat makanan yang dibutuhkan dalam proses pertubuhan ternak. Oleh karena itu hijauan dan konsentrat perlu diformulasikan menjadi suatu pakan yang memiliki kualitas yang tinggi (Siregar, 1995). Pertumbuhan berat badan pada sapi Bali rata-rata lebih rendah dibanding sapi-sapi jenis sapi impor. Hasil penelitian menunjukkan bahwa pertambahan berat badan pada sapi bali hanya $0,156 \mathrm{~kg} / \mathrm{ekor} / \mathrm{hari}$ lebih rendah dari sapi impor jenis peranakan Friesian Holstein (PFH) yakni 1,09 kg/ekor/hari 
(Nurwahidah $d k k .$, 2016). Pemberian suplemen Urea Molasses Blok (UMB) 250 gram/ekor/hari dapat meningkatkan pertambahan bobot badan Sapi Bali dengan rata-rata rata 0,528 kg/ekor/hari (Sumeta, 2008).

\section{Kegiatan Praktek Lapangan}

Kegiatan ini bertujuan untuk lebih memperdalam pengetahuan dan keterampilan dari para konsumen. Gambaran pelaksanaan kegiatan ini secara lengkap disajikan pada Gambar 3.

Salah satu jenis inovasi teknologi dalam bidang teknologi pakan yang diperkenalkan dalam kegiatan ini adalah teknik formulasi bahan dalam pembuatan pakan suplemen yang lebih dikenal dengan istilah Urea Molases Blok (UMB).

UMB merupakan salah satu jenis produk pakan suplemen untuk ternak sapi pedaging. Produk tersebut dapat dicetak menyerupai bentuk blok atau silinder. Salah satu tujuan dilakukannya proses pencetakan adalah agar pakan suplemen tersebut lebih mudah untuk dimanfaatkan oleh ternak dengan cara dijilat. Formulasi produk disusun dalam bentuk komposisi bahan dengan nutrisi yang berimbang. UMB memiliki bentuk padat dan terbuat dari berbagai macam sumber bahan pakan seperti, molasses (tetes tebu) sebagai sumber energi, pupuk urea sebagai sumber $\mathrm{N}$ untuk kebutuhan protein mikroba dalam rumen, garam dapur untuk memberikan cita rasa pada UMB, vitamin serta mineral mix sebagai sumber vitamin dan mineral. Produk UMB berbentuk padatan/blok berisi komposisi nutrisi yang lengkap. Produk dapat dibuat dalam berbagai bentuk dengan harapan mudah dikonsumsi oleh ternak. Pakan yang mengandung protein dan mempunyai nilai energi tinggi harus senantiasa tersedia pada pakan ternak. Untuk membantu proses pencernaan dalam tubuh ternak agar berjalan secara efektif dan efisien tentunya dibutuhkan bahan pelengkap atau bahan tambahan. Penggunaan pupuk urea ditujukan sebagai sumber Nitrogen Non-Protein (NPN) yang digunakan dalam proses fermentasi mikroba dalam rumen. Produk pakan suplemen ini dapat diberikan pada ternak yang gembalakan ataupun yang dikandangkan (Prasetyono, 2014). Pemberian pakan suplemen UMB yang dikombinasikan dengan rumput lapangan memberikan hasil pertambahan berat badan berkisar 0,659 kg/ekor/hari. Kadar protein kasar mencapai 37,76\% dengan kandungan bahan kering mencapai 84,24\% (Sariubang, 2010). Pemberian UMB dapat mengatasi defisiensi mineral pada ternak sapi (Delima, 2008).
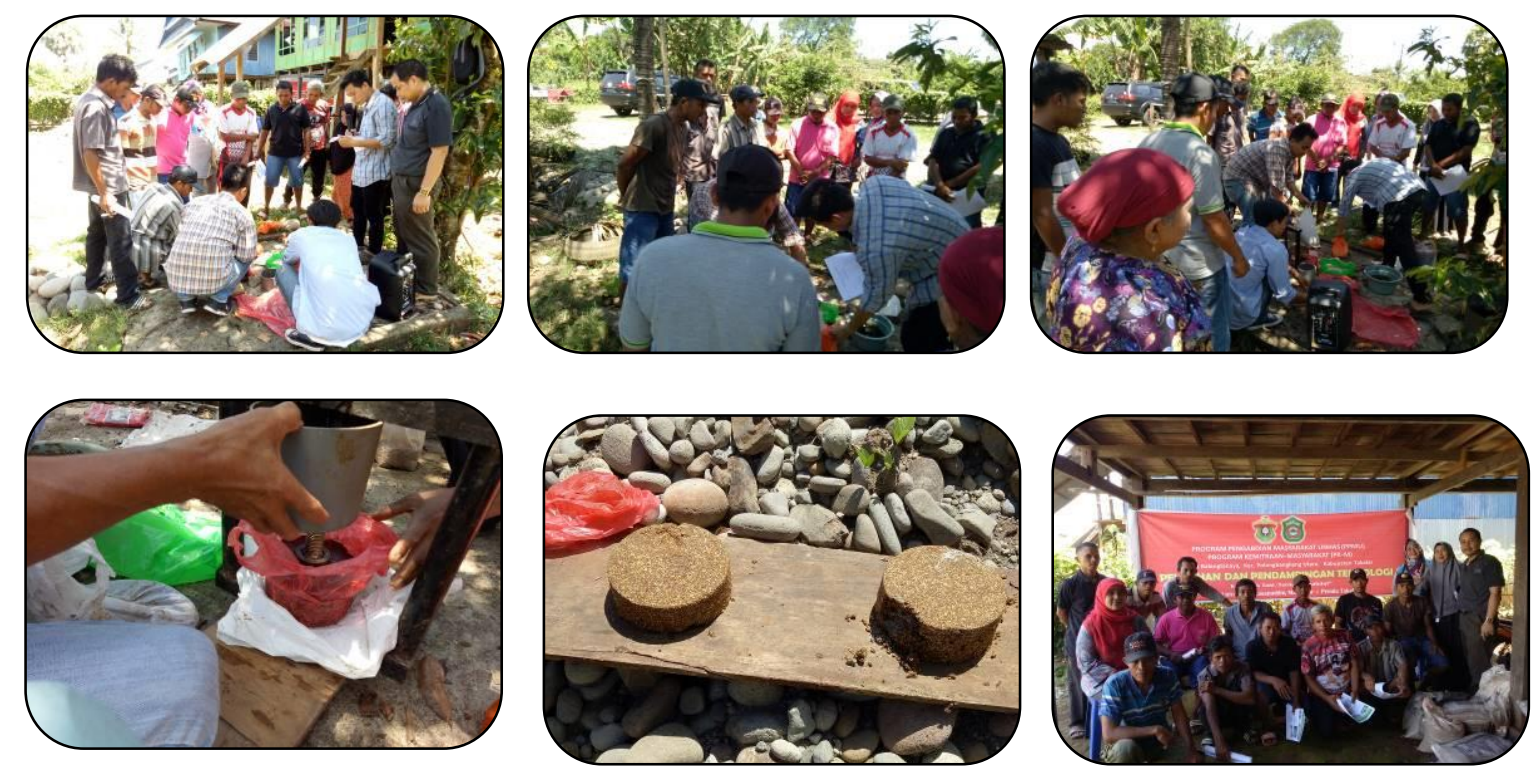

Gambar 3. Kegiatan praktek lapangan pembuatan pakan pakan suplemen urea molasses block (UMB) pada Kelompok Tani Ternak "Sikatutui di Desa Balangtanaya, 
Salah satu upaya dalam meningkatkan kesuburan tanah adalah dengan pemberian pupuk organik. Jenis pupuk ini diperoleh dari alam dan memiliki jenis unsur hara yang relatif lebih lengkap. Residu bahan kimia harus terbebas dari kontaminasi terhadap produk-produk pertanian. Dengan demikian bahan-bahan tersebut diharapkan akan aman dikonsumsi oleh manusia.

Jenis bahan organik yang dapat dimanfaatkan sebagai bahan baku pupuk organik adalah limbah urin. Limbah tersebut adalah hasil proses metabolisme ternak. Produk pupuk organik dari urin lebih dikenal dengan istilah biourin. Mikroba pengikat nitrogen maupun mikroba dekomposer digunakan untuk memfermentasi biourin. Pada biourine, kandungan unsur nitrogen lebih tinggi dibandingkan urin segar (Olla, 2012). Jenis hasil ikutan (by-product) lain yang berpotensi untuk dikembangkan adalah kulit sapi. Produk hasil ikutan ini dapat dimanfaatkan sebagai bahan baku kerupuk kulit (Said, 2018).

\section{KESIMPULAN DAN SARAN}

1. Penurunan produktivitas ternak salah satunya disebabkan karena rendahnya pengetahuan mitra terkait dengan inovasi teknologi

2. Inovasi teknologi dalam bidang peternakan perlu didorong dan diaplikasikan kepada petanipeternak sebagai wujud kepedulian perguruan tinggi terhadap peningkatan produktivitas ternak

3. Program pelatihan dan pendampingan teknologi telah menjadi sumber inspirasi dan inovasi baru bagi para anggota kelompok tani-ternak "Sikatutui" di Desa Balangtanaya, Kecamatan Polombangkeng Utara, Kabupaten Takalar khususnya dalam pengembangan teknologi pakan dan pengolahan limbah ternak

\section{UCAPAN TERIMA KASIH}

Tim penulis mengucapkan terima kasih kepada Kementerian Riset, Teknologi dan Pendidikan Tinggi, Rektor Universitas Hasanuddin, Ketua Lembaga Penelitian dan Pengabdian Kepada Masyarakat (LP2M) Universitas Hasanuddin atas dukungan pendanaan kegiatan melalui Program Pengabdian kepada Masyarakat Unhas (PPMU) pada skim Program KemitraanMasyarakat (PK-M), adik-adik para mahasiswa serta Pemerintah Kabupaten Takalar dan mitra kelompok tani/ternak "Sikatutui" atas kerjasamanya dalam pelaksanaan pendampingan teknologi ini.

\section{DAFTAR PUSTAKA}

Andang, S dan Indartono. 2014. Teknologi Pakan untuk Sapi Perah, Jakarta

Delima, M. 2008. Pengaruh Pemberian Urea Molases Mineral Blok terhadap Kadar Mineral Serum Sapi yang Memperlihatkan Gejala Defisiensi Mineral. Agripet. Vol.8 (1): 45-49.

Nurwahidah, J., A.L.Toleng dan M.N. Hidayat. 2016. Pengaruh Pemberian Pakan Konsentrat dan Urea Molases Blok (UMB) Terhadap Pertambahan Berat Badan Sapi Potong. Jurnal Ilmu dan Industri Peternakan. Vol.2 No. 2, Hal. 111-121

Olla, J.B. 2012. Pemanfaatan Limbah Ternak (Bio Urin). Jurusan Peternakan. Sekolah Tinggi Penyuluhan Pertanian Malang. Badan Pengembangan SDM Pertanian, Kementerian Pertanian, Malang.

Pasaribu, T. 2007. Produk fermentasi limbah pertanian sebagai bahan pakan unggas di indonesia. Jurnal Wartazoa. Vol. 17 (3) : 109-116.

Pemda Takalar. 2017. Kabupaten Takalar dalam Angka 2017.

Prasetyono, R.C. 2014. Teknik Pengolahan UMB (Urea Molases Blok) Untuk Ternak Ruminansia. Balai Pengkajian Teknologi Pertanian Kepulauan Riau. Badan Penelitian dan Pengembangan Pertanian. Kementerian Pertanian, Jakarta.

Said, M.I. 2014. By Product Ternak. Teknologi dan Aplikasinya. IPB Press, Bogor. 
Said, M.I. 2018. Histologi dan Ilmu Dasar Pengawetan Kulit. Deepublish, Yogyakarta.

Sariubang, M. 2010. Kajian Pemanfaatan Pakan Lokal dan Urea Molases Blok (UMB) untuk Penggemukan Sapi Potong di Kabupaten Pinrang, Sulawesi Selatan. Prosiding Seminar Nasional Teknologi Peternakan dan Veteriner, Makassar.

Siregar, S. 1995. Sapi Perah. Penebar Swadaya. Jakarta.

Soeradji. 1978. Peternakan Umum. Yasaguna. Jakarta.

Sumeta, I. 2008. Pengaruh Pemberian Suplemen Urea Molasses Block (UMB) terhadap Pertambahan Bobot Badan Sapi Bali Di Kabupaten Pesisir Selatan. Tesis. Fakultas Peternakan Universitas Andalas, Padang. 